\title{
EX-OFFICIO RIGHTS OF THE JUDGES IN SIGNATING THE HOLDER OF CURRENCY: HADHANAH IN DIRECTIONS OF DIVORCE AT THE RELIGIOUS COURT AS AN EFFORTS OF LEGAL PROTECTION AND ADMINISTRATION OF LEGAL CERTAINITY FOR CHILDREN
}

\author{
Muhammad Fadhly Ase \\ Islamic Law Study Program Student, Concentration of Islamic Family Law \\ UIN Sunan Gunung Djati Bandung \\ Email: fadhly_ase@yahoo.com
}

\begin{abstract}
Child custody (hadhanah) is a problem that often occurs in divorce. This is because divorce often still leaves problems. Divorce only breaks the legal relationship between husband and wife and changes the status of each to a former husband and ex-wife but does not reduce conflicts between them. The conflict between the parents which then leads to a struggle for custody of the child clearly greatly affects the psychological condition of the child. It is the duty of a judge to provide the best interests as a form of protection for the child. The results of this study indicate: the right of ex officio judges is used or applied in the context of certainty, justice and legal benefits for both parties and especially for the child himself, hadhanah or post-divorce care for the child places the child's position as a party that must be protected and is a joint obligation of both parents. in the best interest of the child.
\end{abstract}

Keywords: Children, Hadhanah, Divorce, Protection, Parents.

\section{A. INTRODUCTION}

The issue of child support after divorce is often a problem because sometimes children's rights are seriously ignored and not taken care of, especially those related to the basic rights of children, namely the cost of maintenance, education, shelter and other visitor facilities. Even though parents are no longer united in one family, the issue of fulfilling the child's livelihood remains the responsibility of the parents and this should not be transferred to other people, including parents, relatives, and others. In line with Law Number 1 of 1974 concerning Marriage, article 41 paragraph 3, namely: The court can oblige the ex-husband to provide living expenses and / or determine an obligation for the ex-wife. Then in the Compilation of Islamic Law it is explained in article 56 point $\mathrm{d}$, that all hadhanah costs and child support are the responsibility of the father according to his abilities, at least until the child is an adult who can take care of himself ( 21 years).

Some of these hadhanah suits are independent and some are assessors in divorce cases. However, many claims or applications for divorce that are filed do not coincide with the hadhanah lawsuit, so that if the judge does not give a verdict regarding hadhanah, it is feared that the child is being cared for by parties who are unable or incompetent to care for and educate, behave badly or even have the heart to harm the child. Therefore, in deciding a divorce case at the Religious Court / Syar'iyah Court, the judge's consideration is urgently needed through his ex officio right to determine child custody as a form of protection and legal certainty for children who are victims of divorce despite the ruling. not asked by the husband or wife in the petitum of their lawsuit / petition. 
Child custody in Islam is emphasized in the care of the mother, as long as nothing prevents her from being lost, crazy, drunkenness, and other things that are negative in nature. The fuqoha concludes that the mother's family of a child has more rights than that of the father (Arifin \& Anshori, 2019 : 154-155). However, this is different from the judge's decision in the case of decision No 2787 / Pdt.G / 2018 / PA.Bks. In this case, the plaintiff, in this case the wife named NA, and the defendant, in this case the husband named NS, married in 2008 with an excerpt from the marriage certificate No. xxx / xx / VIII / 2008. During the marriage, the husband and wife have been blessed with 2 daughters, in mid-2016 the marriage between the two of them often occurred. As a result of the quarrel, the wife was unable to continue the marriage bond and filed a divorce suit in court in 2018. This lawsuit continued, until there was a lawsuit for reconciliation. In the counterclaim lawsuit, the plaintiff in the reconstruction (in this case the defendant, namely the husband) stated that the custody of the two children was to the plaintiff in the reconstruction. Until the final decision made by the judge, handed down custody of the child to the defendant or plaintiff during the reconstruction (Father).

According to the author's opinion, this is of course contrary to Article 105 of the Compilation of Islamic Law which states that children who are not yet 12 years old are under the care of the mother, as long as there is nothing to abort them. In the case of decision No. 2878 / Pdt.G / 2018 / PA.Bks it is not proven that there is anything that aborts the child's custody of the mother. On the other hand, in the judge's consideration, there is evidence that the defendant (father) of the child committed acts of violence against his child.

Likewise the case at the Sidoarjo Religious Court in the Sidoarjo Religious Court Decision No. 3400 / Pdt.G / 2016 / PA.Sda shows the verdict that punishes the father regarding his obligation to provide for child support, or in fulfilling other children's rights.

Then in the next case, at the Mojokerto Religious Court, there was a lawsuit divorce case, where a wife in her lawsuit only asked for a divorce, without being accompanied by a lawsuit regarding custody and child support. So that the judge of the Mojokerto Religious Court in his decision only gave a verdict in terms of what the wife asked for, as the decision number: 1267 / Pdt.G / 2013 / PA.Mr. However, when the husband objected and submitted an appeal to the Surabaya Religious High Court to overturn the decision of the Mojokerto Religious Court, the Surabaya Religious High Court judge in his decision strengthened the decision of the Mojokerto Religious Court with the addition of the decision to appoint a wife to care for and care for children and to punish the husband to support the child's living, as decided number: 420 / Pdt.G / 2013 / PTA.Sby. Here there are differences of opinion between the Mojokerto Religious Court judges and the Surabaya Religious High Court judges in exercising their ex officio rights in a legal divorce.

With the emergence of the above problems, the writer considers the importance of the ability of judges in implementing legislation without neglecting justice and the values that live in society. For a judge, progressive law is a law that rests on the conviction of a judge, where the judge is not bound by the formulation of a law. Using progressive law, a judge must have the courage to seek and provide justice especially not always. Laws are fair, related to post-divorce rights, a judge has an ex officio, where in deciding a case a judge can come out of standard rules as long as there are logical and appropriate arguments. the 
rules of the Act. In article 41 letter (c) Law no. 1 of 1974 which states "The court can oblige the ex-husband to provide protection fees and / or determine an obligation for the ex-wife". However, in reality what is happening in the Religious Courts at this time, the post-divorce rights decided by the judges are decided ex officio such as iddah, mut'ah and madhiyah livelihoods as a form of protection for the ex-wife, some are not ex officio. officio like hadhanah rights. Child custody (hadhanah) is a problem that often occurs in divorce. This is because divorce often still leaves problems. Divorce only breaks the legal relationship between husband and wife and changes the status of each to a former husband and exwife but does not reduce conflicts between them. The conflict between the parents which then leads to a struggle for custody of the child clearly greatly affects the psychological condition of the child, it is the duty of a judge to provide the best interests as a form of protection for the child.

\section{B. METHOD}

The approach in this study uses a normative juridical research approach. It is called normative legal research because this research is conducted or aimed only at written regulations or other legal materials. Then it is referred to as document study and library research because this research is mostly conducted on primary data in the library (Nasution, 2008).

\section{RESULT AND DISCUSSION}

In upholding the law, there must be a balance between three elements, namely elements of legal certainty, justice and benefit. These three elements must receive balanced attention. The opinion from the interview of the judge above also stated that the three elements cannot be separated, the decision must be based on 3 principles, namely the principles of legal certainty, justice and benefit. So if the judge decides regardless of the usefulness of the decision, it will be useless the decision will be useless and vice versa. So these 3 elements will not be separated.

The view that considers the purpose of law as mere justice is doubtful because justice itself is something abstract. Justice can be in the form of a permanent and continuous willingness to provide for everyone who is due to it, and there are those who see justice as a justification for legal equality as opposed to arbitrariness.

Law functions as a protection for human interests. In order for human interests to be protected, the law must be enforced. Law enforcement can take place normally, peacefully, but it can happen but it can also happen due to legal violations. In this case the law which has been violated must be enforced. Through law enforcement, this law makes a reality, in upholding the law there are three elements that must always be considered, namely: legal certainty (Rchtssicherheit), benefit (Zweckmassigkeit) and justice (Gerechtigkeit) (Mertokusumo, 1993 : 1).

As stated by Sudikno Mottokusumo that the law must be implemented and enforced, everyone hopes that the law can be stipulated in the event of a concrete event. How the law should apply, basically it is not permissible to keep. that is what legal certainty wants. Legal certainty is a justifiable protection against arbitrary action, which means that someone will be able to get something that is expected in certain circumstances. People 
expect legal certainty, because with legal certainty, society will be more orderly. The law has the task of creating legal certainty because it aims at public order. On the other hand, the community expects benefits in implementing or enforcing the law. Law is for humans, so law enforcement or law enforcement must provide benefits or benefits to society. Do not let it be that because the law is enforced or enforced, there will be unrest in the community. The third element is justice. The public has a strong interest that the implementation or enforcement of the law must be fair. Law is not synonymous with justice. The law is general, binding everyone, generalizing. On the other hand, justice is subjective, individualistic and does not generalize (Mertokusumo, 1993 : 2).

Article 41 of Law Number 1 of 1974 concerning marriage has stated that "both the mother and the father are obliged to care for and educate their children, solely on the basis of the interests of the child if there is a dispute over the control of children the court gives a verdict" and article 45 of the Law The Marriage Law states "Both parents are obliged to care for and educate their children as well as possible, until the child is married or can stand alone, solely on the basis of the child's interest even though the marriage between the two parents has broken up". So based on the article above, the right to care for the children of the two people who are obliged to educate and care for children, not only the rights of the husband or the right of the wife (BIP, 2017).

According to Abdul Manan, it is understood that the provisions of Article 41 of Law Number 1 of 1974 concerning marriage as mentioned above, it can be understood that there is a difference between material care responsibilities and caring responsibilities. Article 41 focuses more on the material obligations and responsibilities that are borne by the husband or ex-husband if he is able, and if the husband is unable, the Religious Court can determine otherwise according to his beliefs. (Manan \& Kencana, $2016: 428$ ).

Regarding the responsibilities of the father and mother, this obligation does not disappear even though they are divorced. This is in line with Article 34 paragraph (1) of Law No.1 of 1974 concerning Marriage, where it is explained that the husband has the obligation to fulfill and provide all financial interests that are treated in his household life. If the husband denies his responsibilities, the former wife who happens to be given the burden of administering the local Religious Court to sentence her ex-husband to pay as much hadhanah as the Religious Court deems appropriate.

According to the Imam Shafi'i school of thought that caring means nurturing and educating children who are not mumayyiz (not able to distinguish between good and bad ones), according to Imam Shafi'i opinion if a child who is not yet mumayyiz and his mother has divorced from his father, someone who is more the main and the one who should educate her is her own mother as long as she is not married to another man (Mas'ud, $2007:$ 414). Judging from the requirements of the hadhanah holder, the opinion of the informants is also in line with the opinion of Imam Syafi'i that among them is being able to educate and care for children who are under their care, including maintaining morals, education, health and children's property (if the child has property), a person who performs hadhanah should be able to be trusted to hold a mandate, so that it can better guarantee the care of children. In the matter of residence, if the child is mumayyiz, it will be the choice of the child to live with the mother's father but in the right to care for and educate, it is the right of both parents (Mughniyah, $2015:$ 420). 
Judges as the last place of escape for justice seekers are considered wise and know the law, and even become a place to ask all kinds of questions for the people. From it, it is expected that consideration as a person who is highly knowledgeable and dignified and dignified. The judge is expected to be a wise and active person in solving problems. UU no. 48 of 2009 also requires active judges, because what is aimed at judicial power in Article 24 of the 1945 Constitution is the power of an independent State to administer justice in order to uphold law and justice based on Pancasila for the implementation of the State of Law of the Republic of Indonesia (Mertokusumo, 1998 : 13-14).

Helping the parties from a theoretical point of view can be categorized as "mandatory" (imperative). The basis is Article 58 paragraph (2) Law no. 7 of 1989 as well as those listed in Article $143 \mathrm{RBg}$. Meanwhile, from the point of view of the objective of providing assistance, it is directed towards realizing simple, fast and low cost judicial practices. In addition, from the point of view of the civil procedural law system itself, directly orally and not having to proceed with the help of legal advisors, but in connection with the level of legal intelligence of the Indonesian people in general, the stronger the reasons for helping justice seekers in the process of examining civil cases are in nature. Imperative (Harahap, $1990: 89)$.

When viewed in the context of benefit, the benefit of humans is the main goal of the formation and implementation of shari'ah. Likewise, in terms of judging, humans are ordered by Allah to become the enforcer of justice that is truly just, regardless. This is stated in the Word of Allah SWT. Surah An-Nisa 'verse 135 which reads:

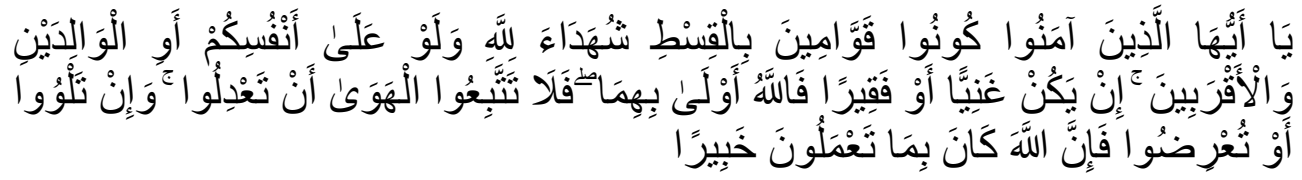

"You who believe, be you a true enforcer of justice, a witness for Allah even though against yourself or your father and family. if he is aya or poor, then Allah knows more about his benefit. So do not follow lust because you want to deviate from the truth. and if you twist (words) or are reluctant to be a witness, then verily Allah is omniscient in all what you are doing" (Kemenag, 2016 : 131).

In this verse, Allah instructs humans to do justice in solving problems between humans. Justice is a system of life that is no longer contested. Do justice to those who are persecuted. Be the enforcer of justice, not out of liking the rich or loving the poor. Because Allah is the One Who makes someone rich and poor, and He knows more about the benefits. Thus, the aim of the teachings of Islam is for the benefit of humans themselves. The same thing is done by the ruler (government of a country) by placing benefit in the form of justice for all Indonesian people as the main objective of the formation of laws in general and specifically in each of its articles (Bahri, 2008 : 92). Likewise, when two or more benefits meet in a problem, then the greater benefit takes precedence. As stated in the rules of fiqhiyyah:

Meaning: "When several maslahat collide, give priority to the biggest one." (Abbas, 2004 : 134). 
If it is related to the application of the ex officio rights of judges in deciding cases for divorce for divorce, the greater benefit is to determine the rights of the wife after divorce rather than granting the petitum of the husband's petition. If the judge only grants what the husband asks in his petition, it will cause harm to the wife after the divorce, especially if she has children.

In the law of fiqhiyah it is also stated:

Meaning: "a danger (mudharat) must be rejected according to one's ability"

From this rule, it can be seen that there is an obligation to avoid the occurrence of harm or in other words that efforts to prevent harm from occurring with all possible efforts are made. Basically Islam does not want harm to its people because it must be eliminated as the hadith of the Prophet SAW which was narrated by Baihaqi from Abi Sa'id al-Khudri.:

Meaning: "From Abi Sa'id Al-Hudri r.a. that Rasulullah SAW. Said: It is not permissible to condemn (danger) and should not be condemned, for those who do harm to others, Allah will do harm to that person, and for those who make it difficult for others, Allah will make it difficult for him ". (Narrated by Baihaqi).

Thus, it is clear that the actions taken by judges at the Religious Courts are not contrary to the prevailing laws and regulations, but also in accordance with the purpose of the formation of the Law itself, namely to provide benefits to humans. The judge used benefit as a basis for consideration in determining the rights possessed by the ex-wife by exercising her ex officio rights which were then realized in the verdict of the divorce case, even though the claim for stipulation of these rights was not in the petitum of the petition for divorce divorce filed by the Petitioner husband).

Moreover, when the judge asked the Respondent about the rights of a wife when her husband was divorced due to divorce, many did not know that they actually had rights that had to be fulfilled by their husbands as a result of the legal act of divorce. So that if it is not protected by using the ex officio rights of the judge, of course the actual rights that should be owned by the ex-wife will be lost. This will lead to kamudharatan for the ex-wife, especially if you have children, it will certainly affect the children's livelihoods as well.

This is done because it is feared that if it is not given it will bring harm to the ex-wife when there is a divorce. And also done to prevent the filing of another lawsuit by the ex-wife to ask for her rights to the Religious Court after the divorce, because this will be burdensome for the ex-wife because in the court process besides requiring money, it will also take a long time. . Because the principle is that in a court case, you must uphold the principle of justice which is carried out simply, quickly and at low cost.

Umar bin Khattab, has also made instructions to qadhi known as risalatul qadha', these instructions contained the principles of civil procedural law which became the guideline for qadhi at that time and remain actual today. One of the instructions which contains the principle of equality before of the law is as follows:

Meaning: "the symbol of wisdom among humans is in your view, your majesty, and your justice so that weak people do not give up on your decisions and honorable people are not ambitious about your cheating." (Ad-Daruquthni, 2008 : 396). 
The meaning contained in these instructions is an order to equalize your view (qadhi) to the parties, sit the parties in the same assembly, view the parties with the same view, give him a fair decision, so that weak people do not feel persecuted because of your decision and honorable people are not greedy for your cheating.

The term child protection is not found in Indonesian Islamic Family Law and / or Indonesian Islamic Marriage Law. The term found is the maintenance and education of children in the Marriage Law, Law no. 1 of 1974 concerning Marriage (BIP, 2017), and the term child care in the Islamic Law Compilation (KHI), the same as the term hadhânah in jurisprudence. In $\mathrm{KHI}$, maintenance or hadhânah is defined as the activities of caring for, maintaining and educating children to adulthood or to be able to stand on their own. Thus there are three key words in child care, namely: raising children, caring for children, and educating children (Kompilasi hukum Islam, 2004).

Meanwhile, the term Child Protection is found in the Child Protection Law, Law no. 23 of 2002 concerning Child Protection, as amended by Law no. 35 of 2014 concerning Amendments to Law no. 23 of 2002 concerning Child Protection. This term is included in Chapter I: General Provisions, article 1 paragraph (2), "Child Protection is all activities to guarantee and protect children and their rights in order to live, grow, develop and participate optimally in accordance with dignity and human dignity, and receive protection from violence and discrimination ".

Thus the term Child Protection in the Child Protection Law is roughly similar to the term child care in Indonesian Islamic Family Law with all its differences. In this paper also uses the term child care, because this paper focuses on the concept of Indonesian Islamic Family and / or Marriage Laws.

Meanwhile, the meaning of Indonesian Islamic Family Law is also roughly the same as the Indonesian Marriage Laws. Indonesian Marriage Laws and Regulations are one of the products of Islamic legal thought. So the purpose of the title of this paper is how to protect children in the Indonesian Marriage Laws.

Theoretically, children get protection and guarantees in the Indonesian Marriage Laws. Even in other non-codified Islamic legal thought products, such as jurisprudence, fatwas and interpretations, children also receive protection and guaranteed rights. However, this is not the case in reality, many children are neglected in their rights in life, both in families that are still intact, father and mother, especially in families whose parents are separated (divorced).

UU no. 1 of 1974 concerning Marriage (referred to as the Marriage Law [UUP]), as the first law which contains the material of marriage, in various articles it contains guarantees of rights and protection of children. Likewise in the Compilation of Islamic Law (KHI). After that, the law was enacted by the government for the same purpose, namely to provide protection and guarantee for the right to care for children. In 2002, Law no. 23 of 2002 concerning Child Protection. This law has even been amended by Law no. 35 of 2014 concerning Amendments to Law no. 23 of 2002 concerning Child Protection.

In the Law No. 1 of 1974 (Law No.1 of 1974 concerning Marriage), protection and guarantees for the care of children is stated in article 41 , that when a divorce occurs, either 
the mother or the father is still obliged to care for and educate the children, and that the father is responsible for all the necessary maintenance and education costs for the child. So that the break up of a parent's marriage should not be an excuse for neglecting child care. In order to guarantee and protect the right to care for children in article 45 , that both parents are obliged to care for and educate their children as well as possible. The care and education of children are the rights of children that must be fulfilled (obligations) of the parents.

Compilation of Islamic Law $(\mathrm{KHI})$, it also states what is mandated in the Law No. 1 year 1974. In the KHI defined what is meant by child care in the General Provisions, as mentioned in the introduction. The maintenance period is stated in chapter xiv Child Care Article 98 , namely 21 years of age, the age that is believed to be discriminatory. The next section describes possible family paths to improve child care security and protection.

\section{CONCLUSION}

The right of ex officio judges is used or applied in the context of certainty, justice and legal benefits for both parties and especially for the child himself, hadhanah or post-divorce care for the child places the child's position as a party that must be protected and becomes a joint obligation of both parents for the sake of best for the child. Even though both parents are divorced, their needs must be met so that they can grow and develop optimally both physically and psychologically

\section{References}

Abbas, A. S. (2004). Qawa'id Fiqhiyyah. Pedoman IImu Jaya.

Ad-Daruquthni, I. A.-H. A. B. U. (2008). Sunan Ad-Daruquthni. Pustaka Azam.

Al-Jauziyah, I. Q. (2006). Al-Turuq al-Hukmiyyah fi al-Siyasah al- Syar'iyyah-Hukum Acara peradilan Islam (A. Qihar, Trans.). Pustaka Pelajar.

Arifin, Z., \& Anshori, Muh. (2019). Fiqih Munakahat. Pustaka Pelajar.

Bahri, S. (2008). Metodologi Hukum Islam. Teras.

BIP, T. (2017). Undang-Undang Republik Indonesia Nomor 1 Tahun 1974 Tentang Perkawinan. Bhuana IImu Populer.

Harahap, M. Y. (1990). Kedudukan, kewenangan, dan acara peradilan agama: UU no. 7 tahun 1989. Pustaka Kartini.

Kemenag. (2016). Al-Qur'an dan Terjemahnya. Jakarta: Kementerian Agama Republik Indonesia.

Kompilasi hukum Islam. (2004). Pustaka Widyatama.

Manan, A., \& Kencana. (2016). Penerapan Hukum Acara Perdata di Lingkungan Peradilan Agama Ed. 2.

Marzuki, P. (2020). Teori hukum. Prenada Media.

Mas'ud, I. (2007). Fiqh Madzhab Syafi'i. Pustaka Setia.

Mertokusumo, S. (1993). Bab-Bab Tentang Penemuan Hukum. Citra Aditya Bakti.

Mertokusumo, S. (1998). Hukum acara perdata Indonesia. 
Mughniyah, M. J. (2015). Fiqih Lima Mazhab: Ja'fari, Hanafi, Maliki, Syafi'i, Hambali. Shaf. Nasution, B. J. (2008). Metode Penelitian IImu Hukum. Mandar Maju.

Wantu, F. M. (2012). Mewujudkan Kepastian Hukum, Keadilan Dan Kemanfaatn Dalam Putusan Hakim Diperadilan Perdata. Jurnal DInamika Hukum, 12(3). 